\title{
Hubungan Pengetahuan Dengan Sikap Ibu dalam Pemberian ASI Eksklusif di Wilayah Kerja Puskesmas Pranggang Kabupaten Kediri
}

\author{
(The correlation between mother's knowledge and attitude in giving exclusive \\ breastfeeding at territorial of Public Health in Pranggang - Kediri)
}

\author{
Triatmi Andri Yanuarini, Dwi Estuning Rahayu, Ekanana Prahitasari
}

\begin{abstract}
Exclusive breastfeeding is breast-feeding for 6 months without any additional liquid. According to Health Department of Kabupaten Kediri in 2013, the exclusive breastfeeding program's achievement is $57.2 \%$. The lowest or the worst achievement of exclusive breastfeeding in Kediri is in Public Health center of Pranggang, it is 5.4\%. The purpose of this study is to identify and analyze the correlation between mother's knowledge and attitude in giving exclusive breastfeeding at territorial of Public Health in Pranggang Kediri. The method which used in this study was the correlation of analytical studies using cross-sectional approach. The population of this study were all 54 breastfeeding mothers of babies aged 0-6 months in Pranggang, Punjul and Sumber Agung. The sampling technique in this study was the probability sampling with cluster sampling method. The samples in this study were 48 respondents. The results of the 48 respondents, 36 people (75\%) had good knowledge and 35 people $(72.92 \%)$ had a good attitude about exclusive breastfeeding. Statistical analysis of the data using the Spearman Rank test with a significance level of 0,05 and $\mathrm{df}=46$, it is obtained $(5,694)>t$ table $(2,021)$. It shows that there is correlation between mother's knowledge and attitude in giving exclusive breastfeeding for babies in age 0-6 months at territorial of Public Health in Pranggang. The writer hopes the midwifery will give motivation more to the mothers for giving exclusive breast-feeding.
\end{abstract}

Key words: Knowledge, Mother's Attitude, Exclusive breastfeeding

\section{Pendahuluan}

Menyusui adalah salah satu komponen dari proses reproduksi yang terdiri atas haid, konsepsi, kehamilan, persalinan, menyusui, dan penyapihan. Jika semua komponen berlangsung dengan baik, proses menyusui akan berhasil (Sarwono P., 2009:376).

ASI merupakan makanan pertama, utama dan terbaik bagi bayi, yang bersifat alamiah. ASI mengandung berbagai zat gizi yang dibutuhkan dalam proses pertumbuhan dan perkembangan bayi. Terkait itu, ada suatu hal yang perlu disayangkan, yakni rendahnya pemahaman ibu, keluarga dan masyarakat mengenai pentingnya ASI bagi bayi. Akibatnya program pemberian ASI eksklusif tidak berlangsung secara optimal. Rendahnya tingkat pemahaman tentang pentingnya ASI selama 6 bulan pertama kelahiran bayi dikarenakan kurangnya informasi dan pengetahuan yang dimiliki oleh para ibu mengenai segala nilai plus nutrisi dan manfaat yang terkandung dalam ASI. Selain itu, kebiasaan para ibu yang bekerja terutama yang tinggal di perkotaan, juga turut mendukung rendahnya tingkat ibu menyusui (Dwi Sunar Prasetyorini., 2009:21-33).

Ada beberapa faktor yang membuat sebagian ibu tidak menyusui anaknya. Pertama, gencarnya kampanye produsen susu dan makanan pengganti ASI. Kedua, kurangnya kesadaran ataupun pengetahuan para ibu terhadap pemberian makanan kepada anak. Ketiga, ketiadaan perhatian yang sungguh-sungguh dari para ahli kesehatan untuk menggalakkan kebiasaan menyusui anak. Keempat, kurangnya program kesejahteraan sosial yang terarah, yang dijalankan oleh beberapa instansi pemerintah di negara-negara berkembang (Dwi Sunar Prasetyorini., 2009:11-12).

Pemberian Air Susu Ibu (ASI) Eksklusif di Indonesia, pada bayi 0 hingga 6 bulan masih relatif rendah, berdasarkan Riset 
Kesehatan Dasar 2010 (Riskesdas) bayi yang mendapatkan ASI eksklusif yang mendapatkan ASI eksklusif angkanya hanya sebesar 15,3 persen. Rendahnya pemberian ASI eksklusif ini di sebabkan kesadaran masyarakat dalam mendorong peningkatan pemberian ASI masih relatif rendah (Lusia Kus Anna, 2011).

Hasil penelitian Nana Yuliada dkk menunjukkan bahwa pemberian ASI Eksklusif masih tergolong sangat rendah $(12,5 \%)$, tingkat pengetahuan ibu sebagian besar kategori kurang $(64,4 \%)$, sikap ibu terhadap ASI Eksklusif sebagian besar masih negatif $(71,2 \%)$, ada hubungan antara pengetahuan dan sikap ibu, dan ibu umumnya memiliki kepercayaan keliru tentang ASI Eksklusif. Rendahnya pengetahuan responden diduga disebabkan antara lain kurangnya informasi, kurang jelasnya informasi, dan kurangnya kemampuan responden untuk memahami informasi yang diterima (Nana Yuliana dkk, 2013).

Berdasarkan laporan di Dinas Kesehatan Kota Kediri tahun 2012 diketahui bahwa cakupan pemberian ASI secara Eksklusif di Kota Kediri sebesar 67\% sedangkan di Kabupaten Kediri sebesar 49,52\%. Meskipun terjadi perbedaan, namun masih dapat memenuhi target ASI Eksklusif. Data capaian program gizi ASI Eksklusif menurut Kabupaten Kediri pada tahun 2013 capaian program ASI Eksklusif sebesar 57,2\%. Pencapaian ASI eksklusif di Kabupaten Kediri yang terendah adalah Puskesmas Pranggang sebesar 5,4\%.

Hasil wawancara tanggal 19 Februari 2014 yang dilakukan ke bidan desa Pranggang mengatakan bahwa ibu setelah melahirkan di BPM itu bilang akan memberikan ASI saja setelah pulang. Akan tetapi saat kunjungan ulang ibu nifas ditemukan pisang dikamar untuk tambahan makanan bayi. Bahkan banyak masyarakat beranggapan bahwa madu itu bagus dan dapat diberikan kepada bayi dengan alasan bahwa madu dapat mencegah bayi dari penyakit dan bayi dapat tumbuh lebih cepat. Madu ini merupakan salah satu makanan yang sering diberikan oleh ibu-ibu kepada bayinya.

Berdasarkan uraian diatas peneliti tertarik untuk meneliti tentang Hubungan Pengetahuan dengan Sikap Ibu dalam Pemberian ASI Eksklusif di Wilayah Kerja Puskesmas Pranggang Kabupaten Kediri.

\section{Metode Penelitian}

Desain penelitian yang digunakan adalah analitik dengan menggunakan rancangan cross sectional, dimana peneliti mencoba menggali bagaimana dan mengapa fenomena kesehatan itu terjadi. Populasi dalam penelitian ini adalah seluruh ibu menyusui bayi usia 0-6 bulan di Desa Pranggang, Punjul dan Sumber Agung di wilayah kerja Puskesmas Pranggang Kabupaten Kediri sejumlah 54 orang. Sampel yang digunakan pada penelitian ini adalah sebagian ibu menyusui bayi usia 0-6 bulan di Desa Pranggang, Punjul dan Sumber Agung wilayah kerja Puskesmas Pranggang Kabupaten Kediri yang berjumlah 48 orang. Teknik pengambilan sampel dalam penelitian ini adalah probability sampling dengan metode cluster sampling. Statistik Nonparametris yang digunakan untuk menguji hipotesis komparatif dua sampel yang berkorelasi pada penelitian ini adalah Korelasi Spearman Rank.

\section{Hasil Penelitian}

\section{Data Umum}

1. Umur Ibu Menyusui

Diagram 1 Distribusi Frekuensi Responden Berdasarkan Umur Ibu di Wilayah Kerja Puskesmas Pranggang Kabupaten Kediri.

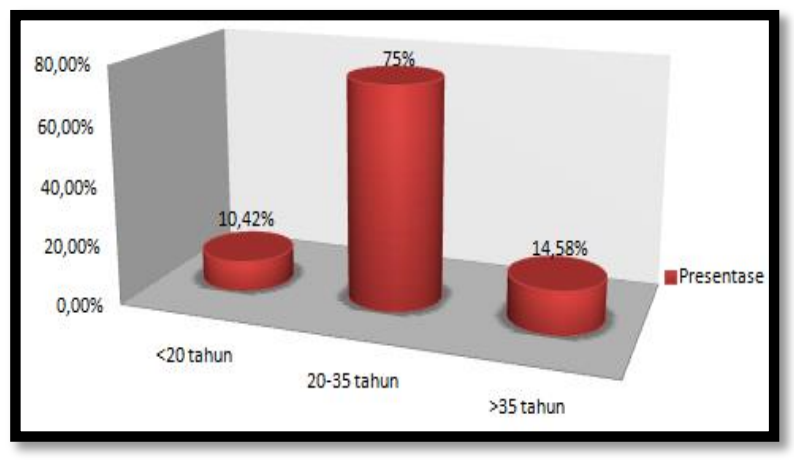

Sumber : Data Penelitian tanggal 4-22 Juni 2014

Dari diagram di atas dapat disimpulkan bahwa sebagian besar umur responden penelitian antara 20-35 tahun $(75 \%)$ 
2. Tingkat Pendidikan

Diagram 2 Distribusi Frekuensi Responden Berdasarkan Tingkat Pendidikan Ibu di Wilayah Kerja Puskesmas Pranggang Kabupaten Kediri.

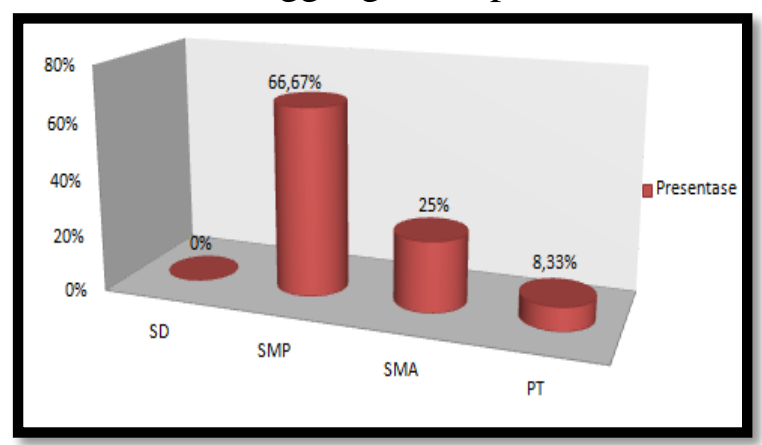

Sumber : Data Penelitian tanggal 4-22 Juni 2014

Dari diagram batang di atas dapat disimpulkan bahwa sebagian besar seluruh responden meliliki tingkat pendidikan $\operatorname{SMP}(66,57 \%)$.

\section{Jenis Pekerjaan}

Diagram 3 Distribusi Frekuensi Responden Berdasarkan Pekerjaan Ibu di Wilayah Kerja Puskesmas Pranggang Kabupaten Kediri.

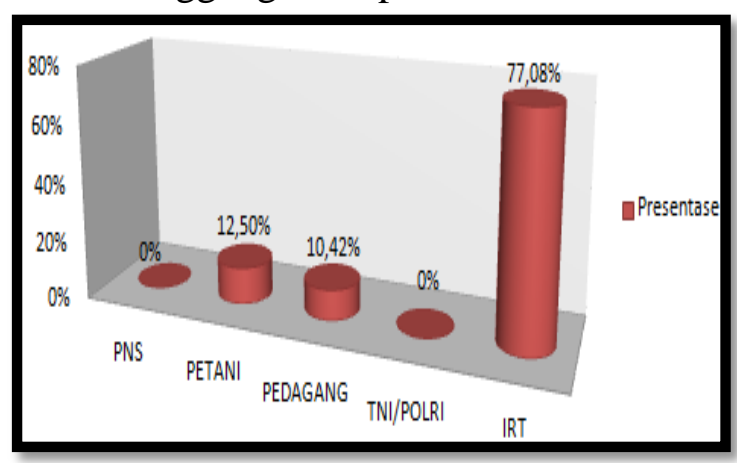

Sumber : Data Penelitian tanggal 4-22 Juni 2014

Dari diagram batang di atas dapat disimpulkan bahwa sebagian besar seluruh responden bekerja sebagai Ibu Rumah Tangga $(77,083 \%)$.

\section{Usia Bayi}

Diagram 4 Distribusi Frekuensi Berdasarkan Usia Bayi Saat ini di Wilayah Kerja Puskesmas Pranggang Kabupaten Kediri

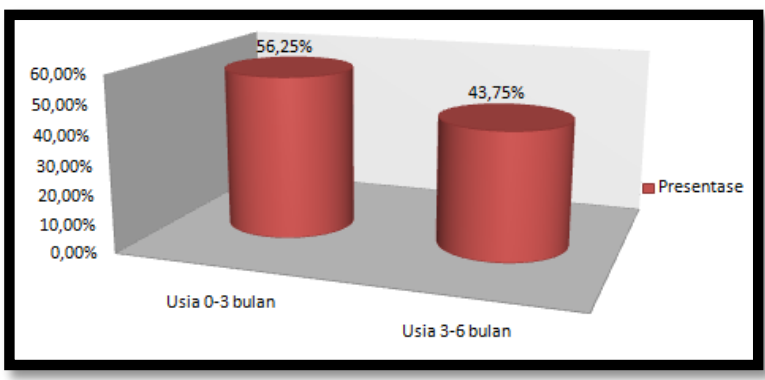

Sumber : Data Penelitian tanggal 4-22 Juni 2014

Dari tabel di atas dapat disimpulkan bahwa sebagian besar seluruh responden memiliki bayi usia $0-3$ bulan $(56,25 \%)$.

\section{Data Khusus}

1. Pengetahuan ibu tentang ASI Eksklusif Diagram 5 Distribusi frekuensi Pengetahuan Ibu Tentang ASI Eksklusif di Wilayah Kerja Puskesmas Pranggang Kabupaten Kediri

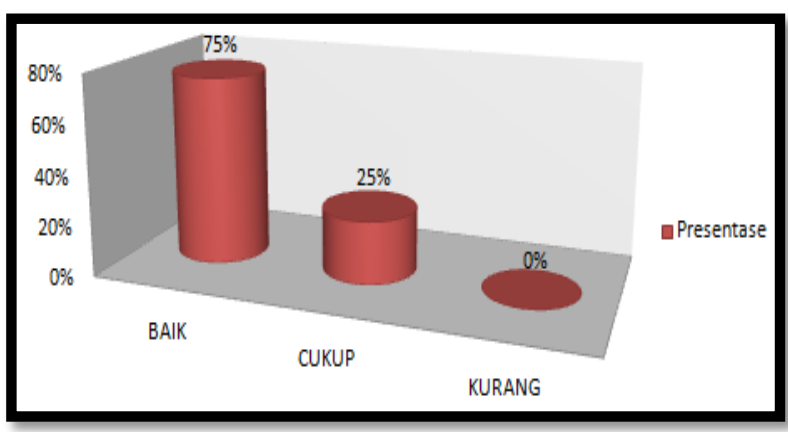

Sumber : Data Penelitian tanggal 4-22 Juni 2014

Dari diagram menunjukkan bahwa sebagian besar responden mempunyai pengetahuan yang baik tentang ASI Eksklusif (75\%).

2. Sikap Ibu dalam Pemberian ASI Eksklusif

Diagram 6 Distribusi frekuensi Sikap Ibu dalam Pemberian ASI Eksklusif pada Bayi Usia 0-6 Bulan di Wilayah Kerja Puskesmas Pranggang Kabupaten Kediri.

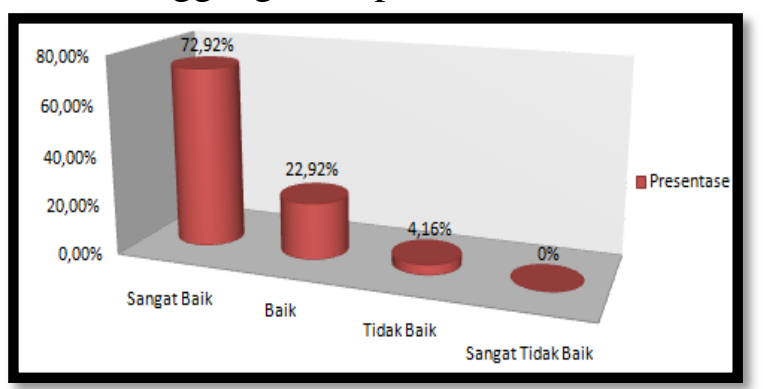


Dari diagram diatas menunjukkan bahwa sebagian besar responden mempunyai sikap sangat baik dalam pemberian ASI Eksklusif pada bayi usia 0-6 bulan $(72,92 \%)$.

\section{Hubungan Pengetahuan dengan Sikap} Ibu dalam Pemberian ASI Eksklusif Tabel 1 Distribusi frekuensi Hubungan Pengetahuan dengan Sikap Ibu dalam Pemberian ASI Eksklusif di Wilayah Kerja Puskesmas Pranggang Kabupaten Kediri

\section{Pembahasan}

Pengetahuan Ibu tentang ASI Eksklusif

Berdasarkan penelitian yang telah dilakukan, didapatkan sebagian besar ibu menyusui di wilayah kerja Puskesmas Pranggang Kabupaten Kediri memiliki pengetahuan yang baik tentang ASI Ekslusif yaitu $75 \%$.

Pengetahuan adalah sebagai sesuatu pembentukan yang terus-menerus oleh seseorang yang setiap saat mengalami reorganisasi karena adanya pemahamanpemahaman baru (Budiman, 2013:4).

Dengan pengalaman seseorang memperoleh banyak informasi dari \%ebenaran pengetahuan. Seseorang menjadi tahu apa yang akan dilakukannya untuk memperoleh pemahaman dari 22.9nformasi tersebut. Oleh sebab itu ${ }^{0}$ pengalaman pribadi pun dapat digunakan sebagai upaya memperoleh pengetahuan. 100 Pengetahuan seseorang juga

Berdasarkan tabel di atas dapat kita lihat bahwa hampir keseluruhan responden memiliki pengetahuan yang baik dan sikap yang sangat baik dalam pemberian ASI Eksklusif sebesar 77,1 \%.

Berdasarkan tabel 1, peneliti melakukan analisa korelasi antara pengetahuan dengan sikap ibu dalam pemberian ASI Eksklusif di wilayah kerja Puskesmas Pranggang Kabupaten Kediri, dengan menggunakan uji korelasi Spearman Rank dan menggunakan taraf signifikansi 0,05 , kemudian didapatkan hasil $r=0,643$. Karena $n$ lebih dari 30, maka $\mathrm{r}$ dimasukkan ke dalam perhitungan $t$ dan didapatkan hasil $t$ hitung $=5,694, t$ hitung dibandingkan dengan $t$ tabel $=2,021$ dengan $\mathrm{dk}=46$. Karena $t$ hitung $>t$ tabel maka Ho ditolak sehingga ada hubungan antara pengetahuan dengan sikap ibu dalam pemberian ASI Eksklusif di wilayah kerja Puskesmas Pranggang Kabupaten Kediri. dipengaruhi oleh faktor internal dan eksternal. Faktor eksternal, salah satunya yaitu informasi/media massa. Informasi dapat dijumpai dalam kehidupan seharihari, yang diperoleh dari data dan pengamatan terhadap dunia sekitar melalui komunikasi. Informasi yang diperoleh baik dari pendidikan formal maupun nonformal dapat memberikan pengaruh jangka pendek (immedate impact) sehingga menghasilkan perubahan atau peningkatan pengetahuan. (A. Wawan dan Dewi M, 2013).

Penelitian Ayu Suryaningtyas tentang hubungan tingkat pengetahuan ibu tentang ASI Eksklusif dengan Perilaku Pemberian ASI di Puskesmas Nguter. Hasil perhitungan yang menggunakan uji Kendal Tau menggunakan program SPSSS.15.00 for Windows diperoleh nilai rho $_{\text {xy }}$ sebesar 0,530 dan nilai probabilitas (p-value $)$ 0,002 lebih kecil dari (alpha) $=$ 0,05 . Berdasarkan kriteria tersebut menunjukkan bahwa hipotesis nol di tolak dan secara statistik ada hubungan tingkat pengetahuan ibu tentang ASI Eksklusif dengan perilaku pemberian ASI Eksklusif secara signifikan. 
Tingkat pengetahuan responden tentang ASI Eksklusif yang baik dipengaruhi oleh beberapa faktor, antara lain tingkat pendidikan dan adanya informasi dari petugas kesehatan. Kemudahan informasi yang berhubungan dengan pengetahuan tentang ASI Eksklusif diperoleh dari beberapa sumber, misalnya dari buku, majalah, media elektronik, petugas kesehatan, serta orangorang disekitar lingkungan ibu. Adanya informasi tentang ASI Eksklusif yang diperoleh ibu baik yang diperoleh ketika melakukan kegiatan Posyandu membantu mereka dalam mengetahui dan memahami tentang pengetahuan ASI Eksklusif yang baik dan benar.

Penelitian Mariane Wowor, tentang hubungan pengetahuan dan sikap dengan pemberian ASI Eksklusif pada ibu menyusui di Puskesmas Bahu Kota Manado. Berdasarkan hasil penelitian pada 38 responden di Puskesmas Bahu, dan setelah dilakukan pengolahan data dengan uji spearnan's rho di dapatkan hasil yang signifikan yaitu $\mathrm{p}=0,000<$ 0,05 sehingga ada hubungan pengetahuan dengan pemberian ASI. Untuk hubungan sikap dengan pemberian ASI didapatkan hasil $\mathrm{p}=0,036<0,05$. Hasil tersebut menunjukkan bahwa ada hubungan pengetahuan ibu dengan pemberian ASI.

Sebagian besar ibu di wilayah kerja Puskesmas Pranggang adalah sebagai ibu rumah tangga sehingga ibu lebih cepat mendapat informasi dari kader. Kader yang biasanya lebih dekat dengan masyarakat juga selalu menginformasikan pentingnya ASI Eksklusif bagi ibu dan bayi. Selain itu, penyuluhan biasanya dilakukan bidan 2-4 minggu sekali. Terkadang saat ada kegiatan posyandu atau ketika ada kegiatan yang lain (seperti ibu yang melakukan pemeriksaan kehamilan juga selalu diberikan penyuluhan tentang ASI Eksklusif).

Tingginya pengetahuan ibu tentang ASI Eksklusif juga dipengaruhi oleh umur ibu yang sebagian besar memiliki umur 20-35 tahun, dimana dari segi umur tingkat kematangan dan kekuatan seseorang akan lebih matang dalam perfikir. Hal ini memudahkan ibu dalam menerima informasi karena mereka sudah lebih matang dalam berfikir. Dari informasi tentang ASI Eksklusif, mereka tahu bahwa ASI Eksklusif sangatlah bermanfaat bagi ibu dan bayi.

Dari hasil penelitian diatas, dapat kita lihat bahwa sebagian besar responden lebih mengerti tentang ASI Eksklusif. Umumnya informasi yang diberikan oleh tenaga kesehatan dapat diterima oleh masyarakat. Namun hal ini tidak terlepas dari setiap individunya sendiri. Banyak ibu yang hanya sekedar tahu saja tanpa memperhatikan dan memahami informasi yang diberikan oleh bidan. Sehingga banyak ibu yang tidak memberikan ASInya pada bayi.

\section{Sikap Ibu Menyusui dalam Pemberian ASI Eksklusif}

Dari penelitian yang telah dilakukan, didapatkan hasil sebagian besar responden memiliki sikap yang sangat baik $(72,92 \%)$ dalam pemberian ASI Eksklusif pada bayi usia 0-6 bulan.

Seseorang akan melakukan suatu perbuatan apabila ia memandang perbuatan tersebut positif dan bila ia percaya bahwa orang lain ingin agar ia melakukannya. Keyakinan-keyakinan berpengaruh pada sikap dan perilaku seseorang untuk melakukan suatu perbuatan atau tidak. Keyakinan ini dapat berasal dari pengalaman dengan perilaku yang bersangkutan dimasa lain dapat juga dipengaruhi oleh informasi tidak langsung mengenai perilaku tersebut (Azwar, 2012).

Sikap mempunyai beberapa ciri, diantaranya sikap bukan dibawa sejak lahir melainkan dibentuk atau dipelajari sepanjang perkembangan itu. Sikap dapat berubah-ubah karena itu sikap dapat dipelajari. Dan sikap dapat berubah pada orang-orang bila terdapat keadaankeadaan tertentu yang mempermudah 
sikap pada orang tersebut (Wawan, dkk, 2011).

Penelitian Winly Wenas, dkk tentang hubungan antara pengetahuan dan sikap ibu menyusui dengan pemberian ASI Eksklusif di Wilayah Kerja Puskesmas Tompaso Kecamatan Tompaso. Menyatakan bahwa sikap responden terhadap ASI Eksklusif lebih banyak berada pada kategori baik yaitu sebanyak 84 responden $(54,2 \%)$ dan sebanyak 71 responden $(45,8 \%)$ berada pada kategori tidak baik. Berdasarkan hasil analisis dengan uji chi-square $\left(x^{2}\right)$ menghasilkan probabiliti sebesar 0,012 pada tingkat kesalahan $(\alpha) 0.05$. Bila nila probabilitas lebih kecil dari tingkat kesalahan maka dapat dinyatakan bahwa terdapat hubungan antara kedua variabel independen dan variabel dependen. Hal ini berarti bahwa terdapat hubungan antara sikap terhadap ASI Ekslusif dengan pemberian ASI Eksklusif pada ibu di wilayah Kerja Puskesmas Tompaso Kecamatan Tompaso.

Sikap (attitude) merupakan konsep paling penting dalam psikologi sosial yang membahas unsur sikap baik sebagai individu maupun kelompok (Wawan, 2011:19). Pengertian lain dari sikap adalah reaksi atau respon seseorang yang masih tertutup terhadap suatu stimulus atau objek (Budiman, 2013:14).

Sikap seseorang dalam kehidupan sehari-hari merupakan reaksi yang bersifat emosional terhadap stimulus. Sikap tentang pemberian ASI Eksklusif oleh responden merupakan faktor yang menentukan seseorang untuk bersedia atau kesiapannya untuk memberikan ASI Eksklusif.

Penelitian Mariane Wowor, tentang hubungan pengetahuan dan sikap dengan pemberian ASI Eksklusif pada ibu menyusui di Puskesmas Bahu Kota Manado. Dari 38 responden di dapatkan hasil yaitu untuk kategori baik paling sedikit yaitu 4 responden $(10,5 \%)$, sedangkan kategori kurang sangat banyak yaitu sebanyak 20 responden $(52,6 \%)$ dan setelah dilakukan pengolahan data dengan menggunakan uji spearman's rho didapat hasil $\mathrm{p}=0,036<0.05$. dengan hasil demikian menunjukkan bahwa ada hubungan sikap ibu menyusui dengan pemberian ASI Eksklusif.

Berdasarkan hasil yang ada, teori menurut Notoatmodjo (2007) sangat tepat yaitu ada 3 komponen utama dalam menentukan sikap seseorang yaitu kepercayaan atau keyakinan, ide dan konsep terhadap suatu obyek, kehidupan emosional atau evaluasi emosional terhadap suatu obyek, dan kecenderungan untuk bertindak (trend to be have).

Sebagian besar ibu di wilayah kerja Puskesmas Pranggang adalah sebagai ibu rumah tangga sehingga ibu lebih cepat mendapat informasi dari kader. Kader yang biasanya lebih dekat dengan masyarakat juga selalu menginformasikan pentingnya ASI Eksklusif bagi ibu dan bayi. Selain itu, penyuluhan biasanya dilakukan bidan 2-4 minggu sekali. Terkadang saat ada kegiatan posyandu atau ketika ada kegiatan yang lain (seperti ibu yang melakukan pemeriksaan kehamilan juga selalu diberikan penyuluhan tentang ASI Eksklusif).

Dari hasil penelitian di wilayah kerja Puskesmas Pranggang dapat dilihat bahwa sebagian besar ibu mempunyai sikap sangat baik dalam pemberian ASI Eksklusif. Faktor yang mempengaruhi sikap antara lain media massa, pengaruh orang lain yang dianggap penting serta pengetahuan ibu juga memiliki pengaruh terhadap sikap dalam pemberian ASI Eksklusif, hal ini dikarenakan semakin banyak aspek positif dan objek yang diketahui maka akan menimbulkan sikap yang positif terhadap objek tertentu.

Sikap yang baik berarti sudah bisa menerima informasi yang diberikan dan dari informasi yang diterima dapat mengambil kesimpulannya. 
Hubungan Pengetahuan dengan Sikap Ibu dalam Pemberian ASI Eksklusif di Wilayah Kerja Puskesmas Pranggang Kabupaten Kediri

Berdasarkan penelitian yang telah dilakukan pada tanggal 4-22 Juni 2014 di wilayah kerja Puskesmas Pranggang Kabupaten Kediri, diperoleh hasil dari 48 responden yaitu sebagian besar ibu memiliki pengetahuan yang baik tentang ASI Eksklusif (75\%) dan sebagian besar ibu memiliki sikap sangat baik dalam pemberian ASI Eksklusif (72,92\%). Dengan menggunakan uji statistika Spearman Rank diperoleh hasil $t$ hitung $(5,694)>t_{\text {tabel }}(2,021)$ sehingga dapat disimpulkan bahwa ada hubungan antara pengetahuan dengan sikap ibu dalam pemberian ASI Eksklusif di wilayah kerja Puskesmas Pranggang Kabupaten Kediri.

Penelitian Resy Tesya Mulianda tentang hubungan pengetahuan dan sikap ibu terhadap pemberian ASI Eksklusif di Posyandu Delima II Desa Baru Dusun II Batang Kuis. Menunjukkan bahwa ibu berpengetahuan baik sebanyak 38 orang $(82,6 \%)$ dan bersikap positif sebanyak 41 orang $(89,1 \%)$ dalam pemberian ASI Eksklusif. Setelah dilakukan uji fisher's exact test disimpulkan ada hubungan signifikan antara pengetahuan dan sikap ibu terhadap pemberian ASI Eksklusif.

Penelitian dari team yang ada dalam jurnal UNPAD tentang hubungan pengetahuan dan sikap dengan pemberian ASI Eksklusif oleh ibu-ibu yang bekerja sebagai perawat di RS Al-Islam Kota Bandung. Analisis data dibagi menjadi analisa univariat dan bivariat. Analisa univariat menggunakan teknik persentase dan skor T. Analisa bivariat menggunakan chi-square. Hasil penelitian menunjukkan adanya hubungan antara pengetahuan dan sikap dengan pemberian ASI Eksklusif oleh ibu-ibu yang bekerja sebagai perawat dengan nilai $\mathrm{p}=0,045$ untuk variabel pengetahuan dan nilai $\mathrm{p}=0,027$ untuk variabel sikap.
Menurut Notoatmodjo (2007) bahwa sebelum seseorang mengadaptasi perilaku, ia harus tahu terlebih dahulu apa arti atau manfaat perilaku tersebut bagi dirinya atau keluarganya. Diharapkan setelah seseorang mengetahui stimulus atau obyek kesehatan kemudian akan mengadakan penilaian atau pendapat terhadap apa yang ia ketahui. Proses selanjutnya diharapkan ia akan melaksanakan atau mempraktekkan apa yang diketahui atau disikapinya (dinilai baik), sehingga setelah seseorang mengetahui apa itu ASI Eksklusif, komposisi, serta manfaat yang dapat ditimbulkan khususnya pada bayi diharapkan dapat bersikap lebih baik dalam pemberian ASI Eksklusif.

Oleh karena itu, diharapkan pemerintah ataupun tenaga kesehatan dapat membantu pemberian informasi tentang ASI Eksklusif dimana erat kaitannya dengan sikap ibu dalam pemberian ASI Eksklusif. Diharapkan hal ini dapat meningkatkan kesadaran pada ibu tentang pemberian ASI Eksklusif dimana banyak mengandung manfaat banyak bagi bayinya dan dirinya sendiri.

Berdasarkan keadaan yang ada di lahan penelitian sebagian besar memiliki pengetahuan yang baik tentang ASI Eksklusif dan juga memiliki sikap yang sangat baik dalam pemberian ASI Eksklusif, hal ini karena mereka mengetahui bahwa ASI Eksklusif dapat memberikan manfaat baik bagi bayi dan dirinya. Sikap ibu dalam pemberian ASI Eksklusif dipengaruhi oleh beberapa faktor antara lain faktor pengetahuan. Sehingga pengetahuan yang baik memiliki pengaruh besar terhadap sikap dalam pemberian ASI Eksklusif. Pada dasarnya pengetahuan yang baik dan sikap yang baik diharapkan ibu dapat berperilaku yang baik dalam pemberian ASI Eksklusif.

\section{Kesimpulan}

Berdasarkan hasil penelitian tentang hubungan pengetahuan dengan sikap ibu dalam pemberian ASI Eksklusif di 
wilayah kerja Puskesmas Pranggang Kabupaten Kediri, maka dapat disimpulkan bahwa :

1. Sebagian besar responden memilikki pengetahuan baik sebanyak 27 orang di wilayah kerja Puskesmas Pranggang.

2. Sebagian besar responden memiliki sikap sangat baik sebanyak 35 orang di wilayah kerja Puskesmas Pranggang.

3. Ada hubungan pengetahuan dengan sikap ibu dalam pemberian ASI Eksklusif di wilayah kerja Puskesmas Pranggang Kabupaten Kediri.

\section{Saran}

\section{Bagi Institusi}

Hasil penelitian ini diharapkan dapat dijadikan sebagai sumber informasi serta bahan pertimbangan untuk penelitian selanjutnya yaitu mengenai faktor-faktor yang mempengaruhi perilaku ibu dalam pemberian ASI Eksklusif.

\section{Bagi Instansi Tempat Penelitian}

Hasil penelitian ini diharapkan dapat dijadikan sebagai sumber informasi bahwa pengetahuan dan sikap ibu dalam pemberian ASI Eksklusif itu baik tapi dalam perilakunya masih rendah. Melalui informasi ini diharapkan kepada petugas kesehatan, diantaranya dengan meningkatkan motivasi pada ibu agar dapat melakukan pemberian ASI Ekslusif.

\section{Daftar Pustaka}

Arikunto, Suharsini. 2010. Prosedur Penelitian. Jakarta. Rineka Cipta.

Azwar, Saifuddin. 2012. Sikap Manusia Teori dan Pengukurannya. Yogyakarta : Pustaka Pelajar Offset.

Budiman dan Agus Riyanto. 2013. Kapita Selekta Kuesioner Pengetahuan dan Sikap dalam Penelitian Kesehatan. Jakarta : Salemba Medika.
Dewi, Vivian Nanny Lia dan Tri Sunarsih. 2011. Asuhan Kebidanan pada Ibu Nifas. Jakarta : Salemba Medika.

Hidayat, A. Aziz Alimul. 2012. Metode Penelitian Kebidanan Teknik Analisis Data. Jakarta. Salemba Medika.

Anna, Lusia Kus. 2011. Rendah, Jumlah Bayi yang Dapat ASI Eksklusif.

Maryunani, Anik. 2012. Inisiasi Menyusu Dini, ASI Eksklusif dan Manajemen Laktasi. Jakarta : CV. Trans Info Medika.

Meiliya,Eny dan Esty Wahyuningsih. 2010. Buku Saku Kebidanan. Jakarta : EGC.

Mulianda, Resy Tesya. 2010. Hubungan Pengetahuan dan Sikap Ibu Terhadap Pemberian ASI Eksklusif di Posyandu Delima II Desa Baru II Batang Kuis 2010. .

Notoatmodjo, Soekidjo. 2010. Metologi Penelitian Kesehatan. Jakarta : Rineka Cipta.

Nursalam. 2009. Konsep dan Penerapan Metodologi Penelitian Ilmu Keperawatan. Jakarta. Salemba Medika.

Prasetyorini, Dwi Sunar. 2009. Buku Pintar ASI Eksklusif. Yogyakarta : DIVA Press.

Prawirohardjo, Sarwono. 2009. Ilmu Kebidanan. Jakarta: PT Bina Pustaka Sarwono Prawirohardjo.

Ramaiah, Savitri. 2006. Manfaat ASI dan Menyusui. Jakarta : PT. Buana Bima Populer.

Roesli, Utami. 2005. Mengenal ASI Eksklusif. Jakarta : Trubus Agriwidya.

Rosita, Syarifah. 2008. ASI untuk Kecerdasan Bayi. Yogyakarta : Ayyana.

Saryono dan Mekar Dwi Anggraeni. 2013. Metode Penelitian Kualitatif dan Kuantitatif dalam Bidang Kesehatan. Yogyakarta. Nuha Medika. 
Suryaningtyas, Ayu. Hubungan Tingkat

Pengetahuan Ibu tentang ASI Eksklusif dengan Perilaku Pemberian ASI di Puskesmas Nguter. 115.

Team, Redaksi. Nursing Journal of Padjajaran University. 2010. Hubungan Pengetahuan dan Sikap dengan Pemberian ASI Eksklusif oleh Ibu-Ibu yang Bekerja Sebagai Perawat Di RS. Al-Islam Kota Bandung.

Wiji, Rizki Natia. 2013. ASI dan Panduan Ibu Menyusui.Yogyakarta : Nuha Medika.

Wawan, A dan Dewi M. 2011. Teori \& Pengukuran Pengetahuan, Sikap, dan Perilaku Manusia. Yogyakarta : Nuha Medika.

Wowor, Mariane dkk. Hubungan Pengetahuan Dan Sikap Dengan Pemberian Asi Eksklusif Pada Ibu Menyusui Di Puskesmas Bahu Kota Manado 2013. 1.

Wenas, Winly dkk. Hubungan Antara Pengetahuan dan Sikap Ibu Menyusui dengan Pemberian Air Susu Ibu Eksklusif di Wilayah Kerja Puskesmas Tompaso Kecamatan Tompaso. 6.

Yuliarti, Nurheti. 2010. Keajaiban ASI. Yogyakarta : ANDI.

Yulianah,Nana dkk. Hubungan Antara Pengetahuan, Sikap Dan Kepercayaan Ibu Dengan Pemberian Asi Eksklusif Di Wilayah Kerja Puskesmas Bonto Cani Kabupaten Bone Tahun 2013.1. 